\title{
Monoclonal Antibody Lym-1
}

National Cancer Institute

\section{Source}

National Cancer Institute. Monoclonal Antibody Lym-1. NCI Thesaurus. Code C1561.

A murine IgG2a monoclonal antibody directed against the HLA-Dr10 protein, a cell surface marker present on over eighty percent of lymphoma cells. When conjug ated with a radioactive isotope, Lym-1 monoclonal antibody selectively transports the cytotoxic radioisotope to HLA-Dr10-expressing tumor cells, thereby sparing healthy B-cells and normal tissues. This agent also mediates antibody-dependent cytotoxicity thereby promoting Raji B-lymphoid cell lysis by human neutrophils. ( $\mathrm{NCl04)}$ 